УДК 577.11/.12:621.798.18:639.21.067

DOI https://doi.org/10.15673/swonaft.v2i84.1890

\title{
USE OF NATURAL BIOPOLYMERS AS PROTECTIVE COATINGS DURING COLD TREATMENT AND STORAGE OF INLAND WATER FISH
}

\author{
S. Patyukov, Ph.D, Associate Professor, A. Fugol, student, \\ A. Palamarchuk, Ph.D, Associate Professor, N. Kushnirenko, Ph.D, Associate Professor \\ Odessa National Academy of Food Technologies
}

Copyring (C) 2020 by author and the journal «Scientific Works»

This work is licensed under Vthe Creative Commons Attribution International License (CC By).

http://creativecommons.org/licenses/by/4.0

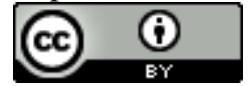

कान ONAFT

Abstract. The urgency of the problem of storage of inland water fish is due to the fact that the production of this raw material is constantly growing both in Ukraine and in many countries around the world. To preserve the quality of these raw materials, refrigerated storage is widely used. It is most advisable to freeze and then store at low temperature.

Cold air is most widely used as a cooling medium, but this method has a number of disadvantages, first of all, it is a low heat transfer coefficient and significant weight loss of fish both during freezing and during storage. In addition, there is oxidation of highly labile fish lipids by oxygen.

In order to intensify the heat transfer process, it is advisable to use liquid media, as a rule - solutions calcium chloride. Calcium chloride solutions have the low freezing point-minus $55^{\circ} \mathrm{C}$. This allows to speed up the process of fish freezing, reduce weight loss, slow down the process of spoilage of fats. However, there will be a problem of salting fish tissues with calcium salts. This is undesirable in terms of deterioration of organoleptic characteristics of the finished product. In addition, calcium ions in significant concentrations lead to a decrease in the moisture holding capacity of proteins, accelerate the processes of lipid spoilage. All this necessitates the use of protective coatings that will protect the raw material from the negative effects of calcium chloride.

To solve this problem, the use of a natural biopolymer - pectin - has been proposed. When pectin interacts with calcium ions, it forms strong three-dimensional jelly-like systems in which calcium ions act as links that bind pectin molecules together.

The paper presents data on the development of recipes and technology for the use of protective coatings based on pectin and their role in maintaining the quality of fish. It is shown that the best properties have a coating that contains $3 \%$ pectin. It is recommended to pre-treat the fish surface with a $1 \%$ citric acid solution, followed by fixing the film with a $1 \%$ calcium chloride solution.

Key words: fish, freezing, storage, protective coatings, pectin

\section{ВИКОРИСТАННЯ ПРИРОДНИХ БІОПОЛІМЕРІВ В ЯКОСТІ ЗАХИСНИХ ПОКРИТТІВ ПРИ ХОЛОДИЛЬНІЙ ОБРОБЦІ ТА ЗБЕРІГАННІ РИБИ ВНУТРІШНІХ ВОДОЙМ}

\author{
Патюков С.Д., Фуголь А.Г., Паламарчук А.С., Кушніренеко Н.М. \\ Одеська національна академія харчових технологій
}

\footnotetext{
Анотація. Актуальність проблеми зберігання риби внутрішніх водойм обумовлена тим, щзо обсяги виробництва иієї сировини безперервно зростають як в Україні, так $і$ в багатьох країнах світу. Для збереження якості иієї сировини широко застосовують холодильне зберігання. Найбільш доцільним $\epsilon$ заморожування з подальшим зберіганням за низької температури.

В якості охолоджуючого середовища найбільш широко застосовують холодне повітря, але ичей спосіб має ряд недоліків, в першу чергу, це низький коефіцієнт тепловіддачі та значні втрати маси риби як в процесі заморожування, так і впродовж зберігання. Крім того, спостерігається окислення високо лабільних ліпідів риби киснем повітря.

3 метою інтенсифікації процесу тепловіддачі дочільно використовувати рідкі середовища, як правило, розчини хлориду кальцію. Розчини хлориду кальцію мають низька температура замерзання -
} 
мінус $55{ }^{\circ} \mathrm{C}$. Це дозволяє пришвидщити процес заморожування риби, зменшити втрати маси, загальмувати процеси псування жирів. Втім, з'являться проблема просолювання тканин риби солями кальиію. Це є небажаним з точки зору погіршення органолептичних показників готової продукиії. Крім того, іони кальцію у значних концентраціях призводять до зниження вологоутримуючої здатності білків, прискорюють прочеси псування ліпідів. Все це обумовлює потребу у використанні захисних покриттів, які будуть захищати сировину від негативного впливу хлористого кальцію.

Для вирішення иієї проблеми запропоновано використання природного біополімеру - пектину. Пектин при взаємодї з іонами кальцџію утворює міџуні трьохвимірні желеподібні системи, в яких іони кальцію виступають в ролі ланок, яки пов'язують між собою молекули пектину.

В роботі наведено дані щзодо розробки рецептури та технології використання захисних покриттів на основі пектину та їх ролі в збереженні якості риби. Показано, щзо найкращзі властивості має покриття, яке містить 3\% пектину. Рекомендовано поверхню риби попередньо обробляти 1\% розчином лимонної кислоти 3 наступною фіксацією плівки 1\% розчином хлористого кальцію.

Ключові слова: риба, заморожування, зберігання, захисні покриття, пектин

Traditionally, packaging in polymer films is used to prevent salting of fish during freezing with salt [1, 6, 7, 17]. The product is wrapped in an impermeable film and then kept in the salt solution at a temperature of minus $35^{\circ} \mathrm{C}$, which allows for 30 minutes or less to bring the temperature in the center of the product to minus $18^{\circ} \mathrm{C}$ $[11,14]$. A number of studies have shown the economic and energy efficiency of the method of freezing in a solution of calcium chloride in poultry packed in film. The authors developed a containerless apparatus for cooling and freezing poultry and fish in a solution of calcium chloride.

In the fishing industry, polymer packaging has become widespread [17]. Currently, along with glazing, the most effective means of protecting frozen fish from oxidative damage [2, 3], contamination, shrinkage is packaging in polymer films. Polyethylene films are quite transparent, do not adsorb moisture, vapor-tight, but relatively well permeable to air, as well as fats and oils. Operating temperature range at which the properties of the film do not change, for low density polyethylene from minus 50 to plus $50{ }^{\circ} \mathrm{C}$, for medium density polyethylene from minus 50 to plus $60{ }^{\circ} \mathrm{C}$, for high density polyethylene from minus 60 to plus $70{ }^{\circ} \mathrm{C}$. Polypropylene films are produced in two types: molded and oriented. Stronger and less vapor-permeable oriented films are more often used for packing frozen fish. Unlike polyethylene, polypropylene is characterized by greater strength, vapor and gas tightness. The operating temperature range of oriented polypropylene is from minus 10 to plus $60^{\circ} \mathrm{C}$, formed from minus 10 to plus $70^{\circ} \mathrm{C}$. As can be seen from these data, polypropylene is unsuitable for storing frozen fish, but can be successfully used for storage and packaging chilled fish products. Polyvinylchloride has low vapor and gas permeability, resistant to fats, oils and organic solvents.

Molded and oriented films can be used for frozen fish packing. The operating temperature range of the molded film from minus 20 to plus $60^{\circ} \mathrm{C}$, oriented from minus 30 to plus $45^{\circ} \mathrm{C}$. Polyvinylchloride differs in that many films made from it contain toxic plasticizers and therefore unsuitable for packaging fish products. For food purposes, only Vitafilm film can be used, which is characterized by low breathability, resistance to fats and oils. However, the range of operating temperatures of this film does not allow to use it for packing of frozen products (from plus 5 to plus $35^{\circ} \mathrm{C}$ ). On the basis of Vitafilm oriented film with an interval of working temperatures from minus 5 to plus $40{ }^{\circ} \mathrm{C}$ was made, but it too can be used only for products with storage temperature not lower than minus $5{ }^{\circ} \mathrm{C}$. Rubber hydrochloride (pliofilm) contains plasticizers, paraffins, antioxidants and other additives that have a toxic effect. Coatings of it are most often used in combination with other films. These films are poorly permeable to water vapor and oxygen. At low content of plasticizers the range of working temperatures from plus 15 to plus $35^{\circ} \mathrm{C}$, and at their high content from minus 10 to plus $25^{\circ} \mathrm{C}$. There are two types of Polyamide films: nylon 6 and nylon 11. The nylon 6 film is transparent, low permeable to gases, fats and oils, but permeable to water vapor. Operating temperature range from minus 40 to plus $150{ }^{\circ} \mathrm{C}$, the film is well welded, but at a high temperature $\left(220^{\circ} \mathrm{C}\right)$. Polyester films are characterized by transparency, low permeability to gases and moderately permeable to water vapor. They can be used as shrinkable films, but they have a high cost and are mainly used in combination with other films to reduce the gas permeability of the latter. Operating temperature range from minus 80 to plus $200^{\circ} \mathrm{C}$.

As the analysis of literature sources from all variety of polymeric film coverings has found application in the fishing industry for prevention of salting only some in view of their instability to action of low temperatures have shown. In addition, despite the high efficiency of preventing salting, the use of polymeric film materials in brine freezing of fish requires additional material and labor costs, as well as special equipment that can significantly increase the cost of frozen fish. Packaging of frozen fish in a polymer film at domestic enterprises has not found application, mainly due to the lack of packaging lines, as well as the need to process fish into fillets to remove sharp, prickly parts. Therefore, the problem of protecting fish from salting should be solved with the use of new cheaper and more reliable substances and methods. 
The quality of frozen fish and the shelf life depend on many factors and, above all, on the degree of freshness of raw materials, freezing method, temperature of refrigerated storage, the degree of shrinkage and lipid oxidation, as well as the type of fish.

One of the most important conditions for obtaining high-quality frozen fish products is the good condition of raw fish, which is sent for processing.

Studies of the impact of freshness of fish before freezing on the quality of frozen fish products have shown that the postmortem state of fish before freezing greatly affects the degree of change in the properties of its muscle tissue during refrigeration. Studies have shown that in frozen fish in the process of refrigerated storage continue to proceed, albeit slowly, mechanochemical processes. The most profound changes in muscle tissue are observed when freezing fish before death. In this regard, it is recommended when justifying the rational processes of refrigeration processing of fish to take into account its postmortem state before freezing. The decrease in the quality of chilled fish significantly affects the grade of frozen fish during refrigerated storage. Changing the duration of storage of fish in ice and in the air before freezing affects the allowable shelf life. A formula has been proposed for calculating the allowable shelf life of horse mackerel, sardines, mackerel, using data on the content of aldehydes in their muscle tissue. The freezing rate is an important factor influencing the quality of frozen fish, as well as the duration of its refrigerated storage. The use of liquid nitrogen to intensify the process of freezing tuna can increase the shelf life of frozen fish by 2.5 - 3.0 times compared with freezing in a solution of sodium chloride.

It is established that lowering the temperature of refrigerated storage of fish increases the allowable shelf life and improves its quality. Changes that occur in frozen fish during refrigerated storage, primarily affect the rheological properties of products, their juiciness, and then on their taste, smell and color. Reducing the temperature of refrigerated storage slows down the processes of oxidation and hydrolysis of lipids [9, 12]. In cod meat frozen with liquid nitrogen to a temperature of minus $10^{\circ} \mathrm{C}$, minus $30^{\circ} \mathrm{C}$ and minus $60{ }^{\circ} \mathrm{C}$ in the process of subsequent storage at a temperature of minus $28{ }^{\circ} \mathrm{C}$ for 12 months there was a decrease in phospholipids, an increase in triglycerides, accumulation free fatty acids, accompanied by lipid oxidation. Shelf life of glazed cod at a temperature of minus $18{ }^{\circ} \mathrm{C}-8$ months, at a temperature of minus $10{ }^{\circ} \mathrm{C}-4$ months, and at a temperature of minus $28^{\circ} \mathrm{C}-15$ months.

Reducing the temperature of refrigerated storage to minus $25^{\circ} \mathrm{C}$ significantly reduces the intensity of histological changes in muscle tissue and oxidative, hydrolytic processes of lipids in muscle tissue of food. The shelf life of products under these conditions increases by 1.5 times. Unsatisfactory storage conditions lead to a decrease in the quality of frozen fish, so one of the most important factors to extend the shelf life and maintain its quality is the stability of the temperature.

The processes of storage of frozen fish are also improved in the direction of the application of glazing, packaging, application of various coatings. In the process of refrigerated storage, fish undergoes a number of biochemical and physical changes associated with enzymatic and biochemical processes and the evaporation of moisture contained in muscle tissue [13]. The main changes that lead to deterioration of product quality are fat oxidation and dehydration of fish (shrinkage). One of the most common ways to prevent dehydration and oxidative spoilage of frozen fish oil is glazing, which is used for blocks of fish and fillets or for large fish frozen in whole. The glaze layer is applied by immersing in water or irrigating the frozen product with water. The glaze is formed in the form of an ice crust, which should evenly cover the surface of the block or fish. The amount of ice formed on the fish during the glazing process depends on the temperature of the block or individual frozen fish, the duration of the glazing, the number of dips and other factors. At long immersion and its repeated repetition the weight of glaze to weight of fish can reach $10 \%$. However, in production conditions, the mass of the glaze is usually from 2 to $7 \%$. The newly formed ice crust in different places on the surface of the block or fish has a different thickness, which leads to different sublimation in different parts of the product. Water covering is effective only for a short period of time, as it can sublimate up to $1 \%$ of the glaze every month. The loss of glaze increases markedly, and the protective properties deteriorate with temperature fluctuations during storage and transportation of frozen fish $[4,8]$.

The use of only water glazing without packaging the product in a polymer film without the addition of antioxidants allows to obtain a slight protective effect. One way to protect frozen fish from oxidation is the method proposed by Papropek of Hull, England. According to it, paper bags made of single-layer paper covered with a polyethylene film inside are used. The purpose of using such bags for freezing fish, in particular herring, is to prevent the decline in the quality of product due to cold burns. The special polymeric covering applied on the bag prevents sticking of the frozen blocks. The fish placed in the bag after removal from the vertical tile freezer represents the finished packaged products. When making a bag, the paper is folded so that the bag is open not from the ends, as usual, but from the side. The empty bag is placed in the loading compartment of the vertical tile apparatus, after which the fish is loaded into it, and the top is filled with water to a level of 
approximately $75 \mathrm{~mm}$ from the upper edge of the bag. Water is used as a binder, and the resulting layer of ice serves as a reliable protection against the effects of oxygen in the wind.

Significant protective effect can be achieved by making in the glazing solution of some substances that inhibit the oxidation of fat $[5,10]$. Positive results in preventing oxidative spoilage of frozen fish were obtained using propolis. Propolis is a bee glue that contains 55\% resin, 30\% wax, $5-10 \%$ mechanical impurities. This substance is brownish-green in color, which contains flavonoids with antioxidant properties. An aqueous solution of alcohol extract of propolis and citric acid (concentration of each component $0.01 \%$ ) is used for processing frozen fish. Treatment with propolis allows to slow down oxidative processes in comparison with control samples.

In addition, it is possible to store frozen fish treated with propolis, at higher temperatures than minus $20-25$ ${ }^{\circ} \mathrm{C}$. In the United States, a recipe for a glazing coating for frozen meat products, which includes beeswax. The product is coated with a water-fat emulsion consisting of fat, water and an emulsifying composition containing 1 to 12 parts by weight of emulsifier and up to 10 parts of edible beeswax. To enhance the protective effect of the glaze, especially to prevent oxidation of fat in the glazing mixture is introduced antioxidants. Butyloxyanisole (BOA) was used in the work of AtlantNIRO in the form of water-milk emulsion with a concentration of $0.5 \%$. It is established that the addition of BOA to the glazing mixture allows to increase the duration of storage of frozen fish in good quality for 1-2.5 months compared with glazing with water only. Another method of adding antioxidants to the glaze solution is that the antioxidant is first dissolved in edible oils (e.g., olive), and then the resulting emulsion is mixed with water and the resulting solution is used for glazing. The advantage of this method is that even in the case of evaporation of the ice crust on the surface of the product remains an oil film containing an antioxidant that prevents the oxidation of fish oil.

The application of polymer films on frozen fish and various fish products can significantly protect them from the oxidation of lipids. Glazing and subsequent packaging in a polymer film under vacuum in comparison with glazing increases the shelf life of frozen fish by about two times.

The results of research indicate an increase in the shelf life of oily fish packed in a polymer film under vacuum, compared with glazed fish packed in cardboard containers.

The protan jelly is used in Norway for the coating of frozen fish, prepared on the basis of alginic acid and alginate with the addition of calcium salts. After application to the product and freezing protan jelly becomes solid and acquires the ability to slow drying. Protan jelly has no odor and protects the product from shrinkage and cold burns. Currently, this type of coating is used in the United States to protect oily fish from freezing (e.g., mackerel), as well as to coat the products of hot smoking, which is then sent for freezing. The coating is easily removed by placing the product under running water.

Various solutions are used for glazing of frozen fish with the addition of starch, inhibiting oxidative spoilage of fat. In Japan, a method and composition for glazing frozen products containing starch hydrolysate is proposed. Starch derivatives improve the ability of foods to retain water. Oxidized starch (treated with hypochlorite) is dispersed in water, dissolved at a temperature of $90{ }^{\circ} \mathrm{C}$, then cooled and stirred, and methylcellulose is added to obtain a $4 \%$ solution. When glazing frozen products with this solution, a homogeneous transparent film is obtained on their surface.

To protect fatty meat and fish products from oxidative rancidity after freezing, carrageenan was used in the form of 0.5 - percent solution, forming a viscous sticky coating on the product. The addition of ascorbic acid creates an improved synergistic effect. Another effective antioxidant was lecithin, which could bind free oxygen. Carrageenan is also used in an edible protective coating with tetracycline, which significantly extends the shelf life.

Polyvinyl alcohol and carboxymethylcellulose are used as water-soluble materials for application to the surface of frozen fish. Polyvinyl chloride (PVC) is a crystalline polymer, the main solvent of which is water. Aqueous solutions of PVC were not exposed to bacteria, are weakly destroyed by a mold and remain for a long time without change. PVC when heated dissolves in glycerin, urea, etc. A positive property of PVC is its high resistance to oils, it does not have the smell and taste.

In England, a method of forming a coating of the following composition is proposed: polyvinyl acetate $(6 \%$ aqueous solution) - 64 weight percent, carboxymethylcellulose - 16, starch - 8, plasticizer - 12. A solution of polyvinyl alcohol can be applied to the surface by double immersion with an interval between immersions of 10 minutes At the same time, a uniform white opaque film about $2 \mathrm{~mm}$ thick is formed on the surface of the fish. Carboxymethylcellulose is an organic substance, soluble in water, cellulose derivative. The CMC solution is a clear liquid. The process of dissolving CMC in water is accelerated by heating, but there is a brown coloration. To avoid this disadvantage, the solution is not heated, and the CMC powder is soaked in water for a day. In Japan, the proposed glazing composition, for the preparation of which can be used carboxyalkylcellulose, alkylcellulose, carboxymethylcellulose and other cellulose derivatives. To prepare the solution, take $3-70$ weight percent of these substances with two or more mono- or polyhydric alcohols (97 - 30 weight percent), 
dissolve in water and get a clear solution. Due to the complexity of this process, as well as appears on the surface of the fish matte shade, these protective coatings in the fishing industry are not yet widely used.

In the United States, a formulation of a dry powder mixture, soluble in water, is proposed for application to the surface of meat and other products. The mixture consists of dry finely divided oxypropylmethylcellulose, glucose, grain hydrolyzate, gelatinized starch in the following proportions (in weight percent): oxypropylmethylcellulose - 3.25; dextrose - 32.25; grain hydrolyzate - 32.25 ; starch - 32.25.

Recently, many countries are conducting research aimed at creating biologically inert protective coatings formed directly on the product. It was found that when using acetoglycerides for glazing frozen fish, the best protective effect in reducing shrinkage and oxidation of fat was obtained than when glazing with water. The works are carried out in two directions. In the first direction, types of protective films based on synthetic polymers are sought, the coatings of which are formed in the cold from aqueous dispersions of polymers. This coating must be removed from the surface before using the product. Work in the second direction is associated with the creation of edible films based on natural polymers. Work is underway to create protective coatings of two types - soluble in cold or hot water and insoluble, but easily absorbed by the human body. Such coatings are applied from the melt at a temperature up to $120^{\circ} \mathrm{C}$ or a concentrated solution. After cooling, the coating adheres securely to the product, forming a dense uniform protective film.

Among biologically inert natural coatings, fat coatings based on polysaccharides and protein derivatives are of the greatest interest. Acetylated monoglycerides are considered to be the most suitable coatings. The coatings obtained with their help are biologically inert, assimilated by the body, have a stable structure that does not change over time.

Abroad, acetylated monoglycerides are increasingly used to protect food. They are obtained from cotton, nut and other oils, as well as from pork lard. Acetylated monoglycerides consist of glycerol, esterified with a mixture of acetic acid and fatty acids of edible fat, and can be applied to the product both in pure form and dissolved in vegetable, mineral oil and others. The temperature of the working solution during processing of the product should be equal to $1-4{ }^{\circ} \mathrm{C}$. The resulting film is $0.1-0.5 \%$ by weight of the product. Films formed from these materials are less permeable to water vapor than cellulose derivatives, and are only slightly inferior in this respect to materials such as nylon, polystyrene, ethylcellulose. Acetylated monoglycerides can be applied to the product in various ways: immersion, spraying and others; the choice of method depends on economic factors and the required coating thickness. When using protective coatings of this type, a significant reduction in losses is achieved due to the tightness of the film to the product, reduces oxidative damage to fat during prolonged storage of the product, the product is protected from microbiological spoilage, retains its natural color.

Along with many positive properties, edible protective films have a number of disadvantages, among which it should be noted that the coatings have insufficient mechanical strength and when manipulated with frozen fish can easily fall off it. In addition, some of the protective coatings may impart flavor to the product.

The possibility of using acetylated monoglycerides to protect food from shrinkage and oxidation has been established, but further research is needed for widespread industrial implementation. A number of acetylated monoglycerides have now been synthesized abroad, differing in the type of raw material, the composition of fatty acids, and properties such as melting point, film-forming ability, and others.

In the United States proposed a method of treating fresh meat with edible acetylated monoglyceride fatty acids. The protective coating is applied to prevent discoloration, taste and weight loss. When processing acetylated monoglyceride, the shelf life of fresh meat increases 3 times, and the quality of the product does not deteriorate (no loss of muscle juice, color change, taste and weight).

To prevent dehydration of meat or fish during refrigerated storage and to add to the product during the subsequent heat treatment of the aroma, an edible film is used, which includes in addition to protective materials spices and seasonings. This coating is stable at low temperatures and is not lost during cooking meat or fish. The edible coating is a water-fat emulsion, the aqueous phase of which contains methylcellulose, which provides the formation of a coherent jelly-like coating. Exemplary composition of the mixture: 6 - 98 parts by weight of fat, 2 - 74 parts of water, $0.1-22 \%$ of the emulsifying composition containing $1-12$ parts of edible emulsifier and 0.3 - 2.0 parts (per 100 parts of emulsion) of methylcellulose low or high viscosity. This mixture can be added spesies: salt, dried onions, pepper, hydrolyzate, sugar, tomato paste, as well as preservatives: sorbic or benzoic acid or their salts. The composition can process any meat product, as well as fish, shrimp and oysters. For coating, frozen or partially frozen product (boiled or raw) is immersed in this composition. The thickness of the resulting coating depends on the viscosity of the solution at processing temperature, product temperature and duration of immersion and is $0.25-2.5 \mathrm{~mm}$ The weight of the film is $15-18 \%$ by weight of the product. For more effective action of the protective film, the storage temperature of the product should be from minus 17 to minus $45^{\circ} \mathrm{C}$, while its quality is maintained during long-term storage.

In the United States developed a method of obtaining an edible protective coating prepared on the basis of fish hydrolyzate with the addition of a natural gelling agent. To obtain the hydrolyzate using waste filleting 
production, including the head and skeleton, which are crushed and subjected to hydrolysis by heating. To accelerate the hydrolysis process add, enzymes such as pepsin, papain, etc. The $\mathrm{pH}$ of the medium is reduced by adding acetic or ascorbic acid. The hydrolysis process is carried out in the presence of sodium chloride, which accelerates the dissolution of some proteins in water. After sterilization of the resulting mixture, solids are separated, and the liquid is concentrated and a gelling agent is added. When immersed in the resulting solution of fish fillets at $10{ }^{\circ} \mathrm{C}$, the mass fraction of absorbed solution may be $5-20 \%$ by weight of the fillet. When the temperature of the processed fillet drops below $4{ }^{\circ} \mathrm{C}$, the solution begins to harden and harden. The quality of fish treated in this way depends on the quality of the raw material, the mass fraction of the absorbed solution and the storage temperature.

An effective edible coating is a mixture consisting of edible starch and a water-soluble salt of alginic acid. This mixture consists of $95-88 \%$ starch and $5-12 \%$ salt of alginic acid. To obtain a glazing solution using 10 $40 \%$ of this mixture. Edible natural starches, hydrolyzed starches, etc. can be used as starch. Sodium alginate, potassium alginate, etc. can be used as alginates. To obtain a coating that can reliably protect the product for a long time, it is desirable to include in an aqueous solution of vegetable oil (mass fraction of $5-20 \%$ by weight of starch and alginate). You can use corn, sunflower, soybean and other oils. After treatment in this solution, fish or shrimp are immersed in an aqueous gelling solution containing calcium ions, to form a shell; this requires no more than 1 minute. After the formation of the shell, the treated product is washed with water or a weak solution of calcium salt to remove excess calcium. After washing, the product is packaged and frozen.

Thus, a promising direction to improve the quality and duration of storage of frozen fish is not only the intensification of freezing processes, but also the use of inexpensive wet-, vapor-, gas-impermeable protective coatings. The use of protective coatings based on natural biopolymers not only helps to prevent reduce the quality of the product, but also creates a number of conveniences in its culinary processing. The introduction of protective films of edible and inedible, applied directly to the product, is important for improving methods of maintaining the quality of frozen fish products. At the same time it is possible to combine separate ways (glazing with packing in a film, a cardboard container, etc.) for a choice of the most economically expedient way.

A promising area of fisheries in Ukraine is the development of pond fish farming. Seriously a problem of more small pond farms are storage of large volumes of large breeds of fish (bi-logo cupid, carp, silver carp, etc.) before descent of ponds for the winter.

Freezing is one of the most progressive ways of canning, which allows to preserve the native properties of such a perishable product as fish. The necessary effect of freezing as a method of preserving food is achieved after lowering the temperature in them to minus $15-20^{\circ} \mathrm{C}$. One of the most important parameters of refrigeration is freezing speed.

Given the large volumes and sizes of fish that need to be preserved without significant deterioration and with minimal loss, when choosing a method of freezing, preference should be given to methods that are characterized by temporal speed.

Studies in recent years have shown the economic and energy efficiency of contact rip freezing of large fish species in a solution of calcium chloride [15]. This method is most affordable for small pond farms that do not require additional material costs and special equipment. Freezing speed in a solution of calcium chloride is $8 \div$ 10 times higher in comparison with air freezing. Despite the significant advantages, a significant disadvantage of contact rip freezing is the salting of fish tissues, which reduces the duration of its next refrigerated storage and quality.

Traditionally, to prevent the diffusion of calcium ions, fish are pre-packaged in a polyethylene film using pre-freezing, which requires special equipment and additional material and labor costs.

In recent years, films based on natural biopolymers, which are formed directly on the surface of fish, are becoming more widespread. Such coatings allow to significantly reduce shrinkage and inhibit lipid damage, thus preserving the original properties of the product for a longer time. Films are obtained from natural compounds: agar, alginic acids, cellulose esters (CMC, MC), pectin. In addition, films based on low-methoxylated pectin and alginic acids are able to prevent the diffusion of calcium ions into the muscle tissue of fish.

In the problem research laboratory of ONAFT researches on development of new methods of primary refrigeration processing of products Pond fish farming from the used coverings on the basis of low-methoxylated pectin Substances are carried out. This film not only reduces the shrinkage and speed of oxidative spoilage of lipids both in the Preservation process and in the freezing process, but also prevents "salting" (diffusion of calcium ions) during freezing of fish.

We propose to use a protective coating based on a natural biopolymer - low-methoxylated pectin-containing extract obtained from fresh apple pomace by alkaline hydrolysis.

The degree of esterification of pectin-containing extract in the process of alkaline hydrolysis was reduced from 70 to $35-20 \%$. 
Film formation based on the ability of low-methoxylated pectin Substances in the presence of calcium ions form strong colds. Pectin molecules interact with each other due to free carboxylic groups that bind calcium ions in a strong framework, which is able to hold enough fluid.

The effect of the degree of esterification, the concentration of pectin substances, the active acidity of the medium and the concentration of calcium ions on the strength characteristics of pectin coatings was investigated.

The degree of esterification was controlled by the duration of alkaline hydrolysis, the concentration of pectin Substances - carbazole method, active Acidity - using a pH meter, the strength of pectin coatings - using a penetrometer.

To characterize the qualitative changes that occur in the muscle tissue of silver carp in the process of freezing and subsequent refrigeration, was determined the mass fraction of water, water holding capacity (WHC) according to GOST 7636-85, active acidity $(\mathrm{pH})$ according to GOST 8756.16 - 70, quality indicators fat according to GOST 7636 - 85 including determining the mass fraction of calcium chloride by calcium - ion trigonometric method according to GOST 7636 - 85 in the subcutaneous layer thickness of $5 \mathrm{~mm}$ after thawing in air and water. In parallel, was determined the mass fraction of calcium ions in the feedstock before freezing.

Thawed fish in air and water at a temperature of $20 \mathrm{C}$ at a ratio of fish and water 1: 3 . Then the fish was cut into pieces and cooked at a ratio of fish and water 1: 2 to readiness and performed organoleptic evaluation of samples of silver carp after heat treatment.

Barrier properties of films with a concentration of pectin in a solution of pectin-containing extract of $1,2,3$, $4 \%$ were investigated using a dialysis beaker (Fig. 1).

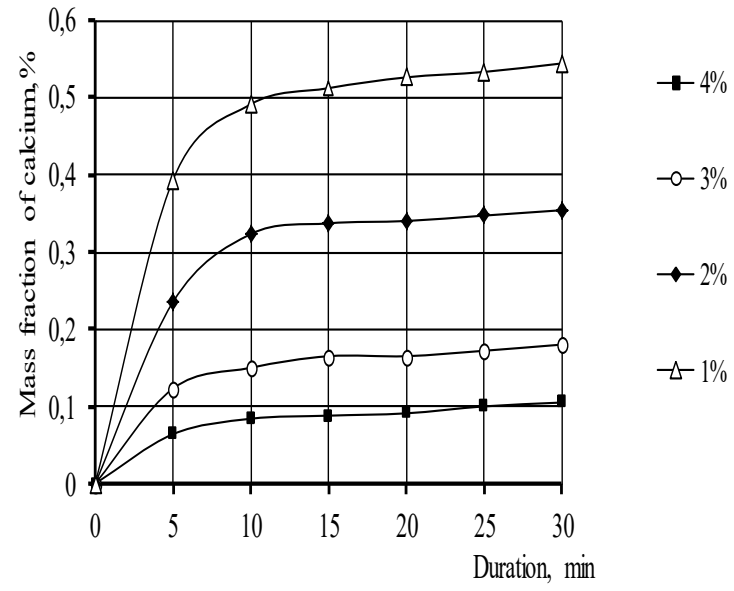

Figure 1 - The effect of the concentration of pectin on the diffision of calcium ions

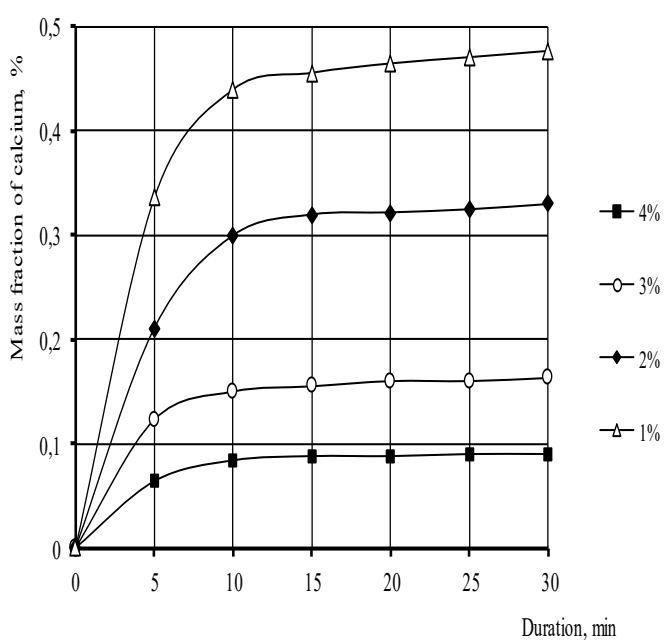

Figure 2 - The effect of pectin concentration and $\mathrm{pH}$ on the diffusion of calcium ions

It has been found that a film with $1 \%$ pectin content is able to inhibit the penetration of calcium into the muscle tissue of fish, but a minimum of calcium penetrates when using coatings with a concentration of pectin 3 and $4 \%$. Moreover, the barrier properties of films with a pectin content of 3 and $4 \%$ differ slightly.

When treating the contact surface of the dialysis glass with $1 \%$ citric acid solution, the amount of diffusing calcium decreases by an average of 3.6 - 4\% (Fig. 2).

This is probably due to the fact that the tendency to gem formation calcites formation sharply with decreasing $\mathrm{pH}$ of the system, due to the increased hydrophilicity of the pectin molecule [6, 7].

When studying the strength characteristics of the films, it was found that the protective coatings obtained using acidification have a higher strength. The concentration of pectin substances also significantly affects the structural characteristics of the films (Fig. 3). 


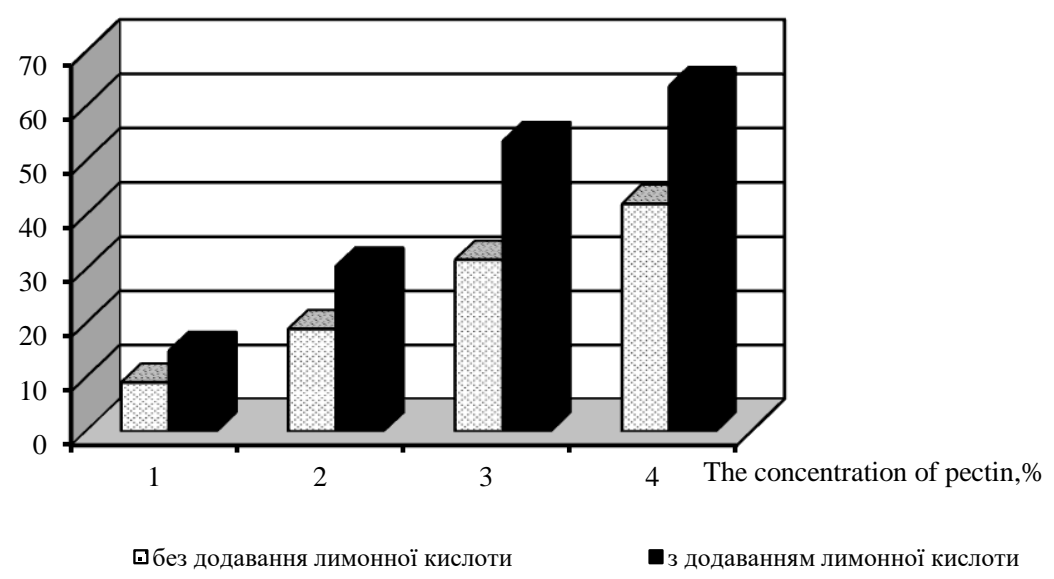

Figure 3 - The effect of pectin concentration and $\mathrm{pH}$ of the medium on the strength characteristics of the protective coating

With increasing concentration of pectin from 1 to $4 \%$, the strength of the film increases by $21.5 \%$ without treatment with citric acid and by $23.5 \%$ with acidification. The increase in the strength of pectin coatings during acidification with citric acid is due to the higher calcium content and, accordingly, a denser "crosslinking" of pectin molecules in the local free carboxyl groups (Table 1).

Table 1 - Saturation of the protective coating with calcium ions

\begin{tabular}{|c|c|c|}
\hline \multirow{2}{*}{$\begin{array}{c}\text { The content of pectin substances } \\
\text { in the protective coating,\%: }\end{array}$} & \begin{tabular}{c}
$|c|$ \\
\cline { 2 - 3 }
\end{tabular} & $\begin{array}{c}\text { The content of calcium ions in the protective coating, } \% \\
\text { with citric acid }\end{array}$ \\
\hline 1 & 1,62 & $\begin{array}{c}\text { without treating the surface of the } \\
\text { fish with citric acid }\end{array}$ \\
\hline 2 & 2,32 & 1,48 \\
\hline 3 & 3,44 & 2,11 \\
\hline 4 & 4,48 & 4,1 \\
\hline
\end{tabular}

The higher content of calcium in protective coatings using citric acid is obviously explained by the ability of acid cations to knock out monovalent metal ions from the bonds, which are locally joined by calcium.

When freezing fish in a solution of calcium chloride using a protective pectin coating ( 3 - $4 \%$ pectin), the amount of diffusing calcium in the fish tissue is reduced by $6.25-6.5 \%$, respectively, compared with fish without coating ( Table 2).

Table 2 - The effect of the type of protective coating on the amount of calcium diffusing into the tissues of fish in the process of brine freezing

\begin{tabular}{|c|c|c|c|}
\hline \multirow[b]{2}{*}{$\begin{array}{l}\text { The concentration of } \\
\text { pectin in the protective } \\
\text { coating, } \%\end{array}$} & \multirow[b]{2}{*}{$\begin{array}{l}* \text { Samp } \\
\text { le }\end{array}$} & \multicolumn{2}{|c|}{ Mass fraction of calcium, $\%$} \\
\hline & & $\begin{array}{c}\text { when treating the } \\
\text { surface of the fish with citric } \\
\text { acid }\end{array}$ & $\begin{array}{c}\text { without treating the } \\
\text { surface of the fish with citric } \\
\text { acid }\end{array}$ \\
\hline \multirow{2}{*}{ Without coating } & I & \multicolumn{2}{|c|}{6,72} \\
\hline & II & \multicolumn{2}{|c|}{2,14} \\
\hline \multirow{2}{*}{$1 \%$} & $\mathrm{I}$ & 1,89 & 1,81 \\
\hline & II & 0,8 & 0,72 \\
\hline \multirow{2}{*}{$2 \%$} & $\mathrm{I}$ & 1,19 & 0,99 \\
\hline & II & 0,56 & 0,51 \\
\hline \multirow{2}{*}{$3 \%$} & I & 0.45 & 0,4 \\
\hline & II & 0,12 & 0,097 \\
\hline \multirow{2}{*}{$4 \%$} & I & 0,3 & 0,26 \\
\hline & II & 0,075 & 0,065 \\
\hline
\end{tabular}

* Notes: I - scaly skin; II - 5 mm of muscle tissue. 
The use of citric acid can reduce the amount of diffusing calcium by another $3-3.5 \%$.

To characterize the qualitative changes in fish, a comparative evaluation of the studied methods was performed on the following indicators: organoleptic evaluation on an 18-point system, WHC on changes in moisture, peroxide and acid fat, shrinkage and calcium content (Table 3).

Table 3 - The impact of the freezing method on the quality of frozen fish.

\begin{tabular}{|c|c|c|c|c|c|c|c|}
\hline \multirow{2}{*}{ Indexes } & \multirow{2}{*}{$\begin{array}{c}\text { Before } \\
\text { freezing }\end{array}$} & \multicolumn{3}{|c|}{ After freezing } & \multicolumn{3}{|c|}{ Refrigeration storage 3 months } \\
\hline & & $\mathrm{I}^{*}$ & II & III & $\mathrm{I}$ & II & III \\
\hline $\begin{array}{l}\text { The content of calcium } \\
\text { ions, } \%\end{array}$ & 2,572 & $2^{2,57}$ & 4,98 & $\begin{array}{l}2,57 \\
5\end{array}$ & 72 & 6,21 & $\begin{array}{l}2,58 \\
0\end{array}$ \\
\hline Weight loss, $\%$ & - & 1,8 & - & - & 3,3 & 1,1 & 0,12 \\
\hline Moisture loss, $\%$ & 19,6 & 42,3 & 21,6 & 22,3 & $1^{48,}$ & 23,5 & 22,3 \\
\hline Acid number, $\mathrm{mg} / \mathrm{g}$ & 4,78 & 5,95 & 5,02 & 4,99 & $03^{10,}$ & 9,21 & 5,86 \\
\hline Iodine number, $\% \mathrm{I}_{2}$ & 0,132 & $\begin{array}{l}0,14 \\
6\end{array}$ & $\begin{array}{l}0,14 \\
4\end{array}$ & $\begin{array}{l}0,13 \\
9\end{array}$ & $\begin{array}{l}0,2 \\
16\end{array}$ & $\begin{array}{l}0,20 \\
8\end{array}$ & $\begin{array}{l}0,17 \\
8\end{array}$ \\
\hline $\begin{array}{c}\text { Organoleptic } \\
\text { evaluation, score. }\end{array}$ & 18 & 17 & 16 & 17,8 & $5^{16,}$ & 15,5 & 17,6 \\
\hline
\end{tabular}

*Note:

-I- air freezing;

- II- brine freezing;

- III- brine freezing using a protective coating based on $3 \%$ pectin solution

Thus, the studies showed the feasibility of using pectin coatings in the contact freezing of fish in a solution of calcium chloride and allowed to determine the conditions for their production.

Freezing in an aqueous solution of calcium chloride is the most effective way to preserve large species of fish in order to maintain high quality for a long time, protective coatings based on pectin can control the diffusion of calcium ions into the muscle tissue of fish.

The strength of the protective coatings increases with decreasing $\mathrm{pH}$ and increasing the concentration of calcium ions in the protective coating. The use of protective coatings based on $3 \%$ pectin solution with pretreatment of the fish surface with $1 \%$ citric acid solution and subsequent fixation of the film with $1 \%$ solution calcium chloride allows to achieve the minimum concentration of calcium ions in the process of brine freezing, which is less than $0.5 \%$ - the value is permissible GOST $7636-85$.

\section{References}

1. Abdelhedi, O., Jridi, M., Nasri, R., Mora, L., Toldrá, F., Nasri, M. (2019). Rheological and structural properties of Hemiramphus far skin gelatin: Potential use as an active fish coating agent. Food Hydrocolloids, 87, p. 331-341. doi:10.1016/j.foodhyd.2018.08.005

2. Barbuzzi, G., Grimaldi, F., Del Nobile, M.A. (2009). Quality decay of fresh processed fish stored under refrigerated conditions. Journal of food safety, 29(2), p. 271-286. Doi:10.1111/j.1745-4565.2009.00156.x

3. Boran, G., Karaçam, H., Boran, M. (2006). Changes in the quality of fish oils due to storage temperature and time. Food Chemistry, 98(4), 2006, p. 693-698. doi:10.1016/j.foodchem.2005.06.041

4. Chamanara, V., Shabanpour, B., Khomeiri, M., Gorgin, S. (2013). Shelf-Life Extension of Fish Samples by Using Enriched Chitosan Coating with Thyme Essential Oil. Journal of Aquatic Food Product Technology, 22(1), p. 3-10. doi:10.1080/10498850.2011.621583

5. García-Soto, B., Fernández-No, I. C., Barros-Velázquez, J., Aubourg, S. P. (2014). Use of citric and lactic acids in ice to enhance quality of two fish species during on-board chilled storage. International Journal of Refrigeration, 40, p. 390-397. doi:10.1016/j.ijrefrig.2013.12.010

6. Kim, H. J., Son, K. T., Lee, S. G., Park, S. Y., Heu, M. S., Kim, J.-S. (2016). Suppression of lipid deterioration in boiled-dried anchovy by coating with fish gelatin hydrolysates. Journal of Food Biochemistry, 41(2), e12331. doi:10.1111/jfbc.12331 
7. Martin Xavier, K. A., Hauzoukim, Kannuchamy, N., Balange, A. K., Chouksey, M. K., Gudipati, V. (2017). Functionality of chitosan in batter formulations for coating of fish sticks: Effect on physicochemical quality. Carbohydrate Polymers, 169, p. 433-440. doi:10.1016/j.carbpol.2017.04.041

8. Pastoriza, L., Cabo, M., Bernárdez, M., Sampedro, G., Herrera, J. Combined effects of modified atmosphere packaging and lauric acid on the stability of pre-cooked fish products during refrigerated storage. European Food Research and Technology, 215(3), 2002, p. 189-193. doi:10.1007/s00217-002-0557-3

9. Rajesh, R., Ravi Shankar, C. N., Srinivasa Gopal, T. K., Varma, P. R. G. (2002). Effect of vacuum packaging and sodium acetate on the shelf life of seer fish during iced storage. Packaging Technology and Science, 15(5), p. 241-245. doi:10.1002/pts.586

10. Ramírez-Guerra, H. E., Castillo-Yañez, F. J., Montaño-Cota, E. A., Ruíz-Cruz, S., Márquez-Ríos, E., Canizales-Rodríguez, D. F., Ocaño-Higuera, V. M. (2018). Protective Effect of an Edible Tomato Plant Extract/Chitosan Coating on the Quality and Shelf Life of Sierra Fish Fillets. Journal of Chemistry, p. 16. doi:10.1155/2018/2436045

11. Vital, A. C. P., Guerrero, A., Ornaghi, M. G., Kempinski, E. M. B. C., Sary, C., Monteschio, J. de O., do Prado, I. N. (2018). Quality and sensory acceptability of fish fillet (Oreochromis niloticus) with alginatebased coating containing essential oils. Journal of Food Science and Technology. doi:10.1007/s13197-018-3429$\mathrm{y}$

12. Wang, H., Liu, F., Yang, L., Zu, Y., Wang, H., Qu, S., Zhang, Y. (2011). Oxidative stability of fish oil supplemented with carnosic acid compared with synthetic antioxidants during long-term storage. Food Chemistry, 128(1), p. 93-99. doi:10.1016/j.foodchem.2011.02.082

13. Zhou, R., Liu, Y., Xie, J., Wang, X. (2011). Effects of combined treatment of electrolysed water and chitosan on the quality attributes and myofibril degradation in farmed obscure puffer fish (Takifugu obscurus) during refrigerated storage. Food Chemistry, 129(4), 1660-1666. doi:10.1016/j.foodchem.2011.06.028

14. Zaytsev, V. P. (1962). Holodilnoe konservirovanie ryibnyih produktov. M.: Pischepromizdat, 462, 4.

15. Mizhueva, S.A., Manuhin, A.S., \& Hvalova, L.I.(1992). Vliyanie zamorazhivaniya v rastvore hlorida kaltsiya na kachestvo ryibyi // Sovershenstvovanie metodov holodilnogo konservirovaniya pischevyih produktov. $62-67$

16. Karpovich, N. S., Donchenko, L. V., Nelina, V. V., Kompantsev, V. A., \& Melnik, G. S. (1989). Pektin. Proizvodstvo i primenenie.

17. Hvan, E.A. (1975). Zaschitnyie pokryitiya dlya ryibnyih produktov.-M.:VO Agropromizdat. 45.

Cite as

S. Patyukov, A. Fugol, A. Palamarchuk, N. Kushnirenko. Use of natural biopolymers as protective coatings during cold treatment and storage of inland water fish // Наук. пр. / Одес. нац. акад. харч. технологій. Одеса, 2020. Т. 84, вип. 2. С. $57-66$.

Отримано в редакцію 10.08 .2020

Прийнято до друку $\quad 25.10 .2020$
Received 10.08.2020

Approved 25.10.2020 